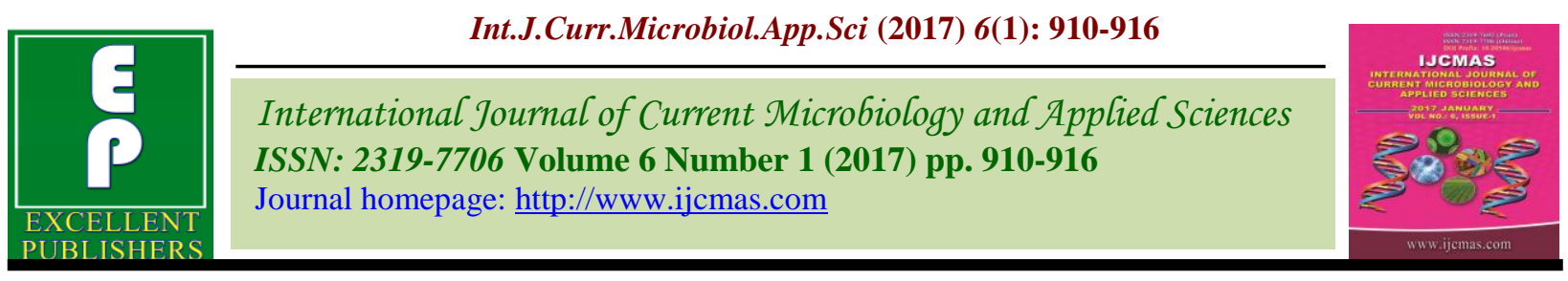

Review Article

http://dx.doi.org/10.20546/ijcmas.2017.601.107

\title{
Antiretroviral Therapy that Includes, Protease Inhibitors - Induced Hepatotoxicity: A Review
}

\author{
V.S. Chopra ${ }^{1}$, Mani Goel ${ }^{2 *}$, Jyoti Batra ${ }^{3}$, Jyotsna Sharma ${ }^{4}$ and Kavita Dhar ${ }^{4}$ \\ ${ }^{1}$ Department of Pharmacology, Santosh Medical College, Ghaziabad \\ ${ }^{2}$ L.L.R.M, Medical College, Meerut, India \\ ${ }^{3}$ Department of Biochemistry, Santosh Medical College, Ghaziabad, India \\ ${ }^{4}$ Department of pharmacology, Santosh Medical College, Ghaziabad, India \\ *Corresponding author
}

\section{A B S T R A C T}

Keywords

Protease Inhibitors,

HIV,

Antiretroviral

Therapy.

Article Info

Accepted:

28 December 2016

Available Online:

10 January 2017
Human immunodeficiency virus (HIV) is a retro virus known to be the primary aetiological agent of Acquired Immunodeficiency syndrome (AIDS). It is reported that about 39 million people globally are living with HIV. HIV infected patients are frequently present with elevated levels of serum alanine aminotransferase (ALT) and aspartate aminotransferase (AST). This has been often attributed to the hepatic effects of Antiretroviral- Protease Inhibitor drugs (PI's). A review of cohort studies investigating the incidence of hepatotoxicity among patients receiving Antiretroviral- Protease inhibitor drugs suggests that the overall rate of ALT and AST elevations is similar among all Protease inhibitor drugs and considering the importance of drug induced hepatotoxicity as major cause of liver damage, this review also throws light on protease inhibitor drugs which induce hepatotoxicity, with their mechanism of liver damage and clinical scenario.

\section{Introduction}

HIV is a retrovirus known to be the primary cause of Acquired Immune deficiency Syndrome (AIDS). Due to the large scale of morbidity and mortality it causes, HIV is fast becoming a major threat in developing countries including the Indian sub-continent. Infection with HIV is associated with prolonged latent period during which the virus continues to actively replicate, usually resulting in symptomatic illness. (1)

\section{Antiretroviral Therapy}

The introduction of combination of antiretroviral therapy has led to significant reduction in morbidity and mortality associated with HIV infections.(2) There are different combination therapies presenting activity against both wild-type and multidrug resistant HIV.

Pharmaceutical agents that can be combined to make up highly active antiretroviral therapy (HAART) can be divided into three categories, namely, nucleoside reverse transcriptase inhibitors (NRTIs), nonnucleoside reverse transcriptase inhibitors (NNRTIs) and protease inhibitors (PIs), based on their mechanism of action. 
With inception of highly active antiretroviral therapy (HAART), the quality of life of HIV infected individuals is gradually improving. The number of people contacting new infections has been on decline globally and those having access to HAART are increasing.

\section{Hepatotoxicity}

Hepatotoxicity is a general term for liver damage. Medications, including those used to treat HIV infection, may cause hepatotoxicity. Drug induced hepatic injury is currently responsible for $<50 \%$ of cases of acute liver failure in the united states.(3) The mechanisms of antiretroviral-induced hepatic toxicity include dose-dependent toxicity, idiosyncratic reactions, hypersensitivity reactions, mitochondrial toxicity and immune reconstitution.(4)

Antiretroviral drugs, particularly nevirapine and ritonavir-boosted protease inhibitors, may cause hepatitis.(5-10) The risk of development of hepatitis is higher in patients with pre-existing liver problems, especially those with HBV and HCV co-infection.(1113)

\section{Classification of Hepatotoxicity}

Liver toxicity is defined as an increase in Aspartate Aminotransferase (AST) or Alanine Aminotransferase (ALT) levels 5 times above the upper limit of normal (corresponding to WHO grade 3-4 toxicity). There has been discrepancy in the classification of hepatotoxicity.

A standard toxicity grade scale is available and is used by AIDS research group. Patients with normal AST and ALT levels before treatment are classified with respect to changes relative to the upper limit of normal UNL.
Hepatotoxicity is classified as grade 0 $(<1.25 \times \mathrm{ULN})$; grade $1(1.25-2.5 \times \mathrm{ULN})$; grade 2 (2.6- $5 \times$ ULN); grade 3 (5.1-10x ULN) and grade $4(>5 \times U L N)$. Severe hepatotoxicity is defined as grade 3 and grade 4 changes in AST and/or ALT levels during highly active antiretroviral therapy.

\section{Protease Inhibitors}

Ritonvir: Ritonavir has been the most frequently implicated PI to cause hepatotoxicity. Sulkowski,et al. recorded severe heptotoxicity defined as a rise in transaminases greater than 5 times normal in $27.3 \%$ of patients treated with ritonavir.(14) cytochrome $\mathrm{P} 450$ inhibition is an important factor in ritonavir heptotoxicity.

Indinavir: Severe acute hepatitis has been reported with indinavir therapy and this may occur early or late in to therapy. $(15,16)$ However the most common laboratory finding in patients on indinavir is unconjugated hyperbilirubinaemia seen in upto $40 \%$ of patients. (17) This occurs due to inhibition of the enzyme uridinediphosphoglucoronoside (UDP) Glucuronosyl transferase that is the enzyme involved in Gilbert's syndrome mutant allele.(18) Despite this frequency, severe hepatotoxicity has been reported in only $3.4 \%$ of patients and in whom therapy must be ceased.

Saquinavir- Severe hepatitis due to saquinavir is uncommon. In clinical trial NV 14256 less than $1 \%$ of patients developed hypertransaminemia levels of squinavir. When used in combination with ritonavir may rise 20 times and the combination is discouraged. (19)

Nelfinavir: It appears to be safer than the other protease Inhibitors, A reterospective study of $118 \mathrm{HCV} / \mathrm{HIV}$ coinfected patients 
receieving PI therapy for longer than 3 months was performed.(20) $38 \%$ of patients receiving NFV therapy and remainder received other protease Inhibitors, indinavir $32 \%$, saquinavir $16 \%$, ritonavir $13 \%$ and amperinavir $1 \%$. The rate of grade 3-4 hepatotoxicity was $3 \&$ in NFV treated group compared to $8 \%$ in the non NFV group.

Amprenavir: There are few reports of amprenavir hepatotoxicity in the literature. In a review of data from 358 adults and 268 children enrolled in phase II and III studies severe hepatotoxicity related to amprenavir was rare. (21)

\section{Mechanism of PI - related Hepatotoxicity}

Substrates of P-glycoprotein, an ATPdependent efflux membrane multidrug resistance transporter, comprise one class of molecules that can limit the absorption of most PIs. For example, oral administration of saquinavir, indinavir, or nelfinavir in knockout mice lacking this transporter resulted in two- to fivefold increases in plasma drug concentrations.(37) Higher plasma drug of Hepatology concentrations can therefore produce toxicities in human patients that might lack P-glycoprotein. While drug interactions should be examined closely whenever prescribing medication in combination with PIs, this is a particularly important consideration with ritonavir, given its powerful inhibition of cytochrome p450 (CYP) 3A4 and its effects on several other mechanisms of drug interactions.(38) These can lead to increased levels of many coadministered medications, and consequently ADRs. Moreover, there is a potential for interaction with nutritional supplements.(39) Physicians should also be aware that patients with chronic viral hepatitis coinfection have additional impairment of CYP3A activity in the presence of ritonavir, compared to HIV patients without viral hepatitis, even at the low doses of $100 \mathrm{mg} /$ day typically used for pharmacokinetic boosting.(40)

Table.1 Incidence of hepatotoxicity in registration trials for selected HIV-1 Protease inhibitors

\begin{tabular}{|l|l|c|c|}
\hline Drug & Definition of liver injury & $\begin{array}{c}\text { No. of patients } \\
\text { studied }\end{array}$ & $\begin{array}{c}\text { Incidence,cases/100 } \\
\text { patients exposed }\end{array}$ \\
\hline Saquinavir (22) & ALT or AST >5* ULN & 442 & 5.7 \\
\hline Indinavir (23) & $\begin{array}{l}\text { ALT or AST >5* ULN } \\
\text { Total bilirubin, 2.5* ULN }\end{array}$ & 1220 & $2.6-4.9$ \\
\hline Ritonavir (24) & ALT >215 IU/L, AST >180 & 1270 & $5.3-9.5$ \\
\hline $\begin{array}{l}\text { Lopinavir/ritonavir } \\
(\mathbf{2 5})\end{array}$ & $\begin{array}{l}\text { ALT > } 215 \text { IU/L, AST >180 } \\
\text { IU/L }\end{array}$ & 612 & $2.2-9.5$ \\
\hline Nelfinavir (26) & ALT or AST >5*ULN & 1297 & $1-2$ \\
\hline Atazanavir (27) & ALT or AST >5*ULN & 1056 & $22-47$ \\
\hline & Total bilirubin > 2.5*ULN & & \\
\hline
\end{tabular}

Note:Data are abstracted from the US Food and Drug Administration-approved prescribing information for each drug. AST, alanine aminotransferase; AST, aspartate aminotransferase; ULN, upper limit of normal. 
Table.2 Incidence of hepatotoxicity in published cohort studies for selected HIV-1 protease inhibitors (PIs).

\begin{tabular}{|c|c|c|c|c|c|c|c|c|c|c|}
\hline \multirow[t]{2}{*}{ Study Design } & \multirow{2}{*}{$\begin{array}{l}\text { No. of } \\
\text { Patients } \\
\text { studied }\end{array}$} & \multirow{2}{*}{$\begin{array}{l}\text { Prevalenc } \\
\text { e of } \mathrm{HCV} \\
\text { infection } \\
\%\end{array}$} & \multirow[t]{2}{*}{$\begin{array}{l}\text { Definition of } \\
\text { Hepatotoxicity }\end{array}$} & \multicolumn{6}{|c|}{$\begin{array}{l}\text { Incidence of Hepatotoxicity, in cases/100 } \\
\text { patients exposed, by drug or regimen. }\end{array}$} & \multirow[t]{2}{*}{ Reference } \\
\hline & & & & Over all & $\begin{array}{l}\mathbf{R} \\
\mathbf{T} \\
\mathbf{V}\end{array}$ & $\begin{array}{l}\text { I } \\
\text { D } \\
\text { V }\end{array}$ & $\begin{array}{l}\mathbf{S} \\
\mathbf{Q} \\
\mathbf{V}\end{array}$ & $\begin{array}{l}\mathbf{N} \\
\mathbf{F} \\
\mathbf{V}\end{array}$ & $\begin{array}{l}\text { other } \\
\text { regimens }\end{array}$ & \\
\hline Retrospective & 748 & 28 & $\begin{array}{l}\text { ALT }>5 * \text { ULN or ALT } \\
>200 \mathrm{IU} / \mathrm{mL}\end{array}$ & 8.5 & - & & - & - & - & (28) \\
\hline Retrospective & 1047 & 26 & $\begin{array}{l}\text { ALT or ALT }>5 * \\
\text { ULN }\end{array}$ & 5 & - & - & - & - & - & (30) \\
\hline Retrospective & 394 & 14 & $\begin{array}{l}\text { AST or ALT }>5 * \text { ULN } \\
\text { and } 1100 \text { IU } \\
\text { above baseline ALT } \\
\text { level }\end{array}$ & 18 & - & - & - & - & - & (31) \\
\hline Retrospective & 222 & 38 & $\begin{array}{l}\text { AST or ALT >5* } \\
\text { ULN or } 3.5^{*} \text { abnormal } \\
\text { baseline level }\end{array}$ & 10 & - & - & - & - & - & (33) \\
\hline Retrospective & 1250 & 46.5 & ALT $* 200 \mathrm{IU} / \mathrm{mL}$ & 7.9 & 6.1 & 4.1 & 6.1 & 1.3 & - & (34) \\
\hline Retrospective & 1477 & 48.1 & $\begin{array}{l}\text { ALT or AST above } \\
\text { baseline level }\end{array}$ & 7.8 & 9.1 & 4.7 & 5.2 & 3.4 & - & (35) \\
\hline Retrospective & 560 & 10.7 & $\begin{array}{l}\text { AST or ALT >10* } \\
\text { ULN and } 1200 \mathrm{IU} \\
\text { above baseline ALT } \\
\text { level }\end{array}$ & 7.9 & - & - & - & - & - & (36) \\
\hline
\end{tabular}

NOTE. ALT, alanine aminotransferase; AST, aspartate aminotransferase; d4T, stavudine; HBV, hepatitis B virus; HCV, hepatitis C virus; LAM, lamivudine; NNRTI, nonnucleoside reversetranscriptase inhibitor; NVP.

\section{Tests}

\section{Liver function tests (LFTs)}

These tests measure whether liver is being damaged. (Things that can damage the liver are viral hepatitis, alcohol, medications, and street drugs.) These tests measure alkaline phosphatase, ALT, AST, albumin and bilirubin. It is important to have a baseline measure of liver health, because it may need to take HIV medications in the future, and some of these medications can cause liver damage.

\section{Hepatitis A, B, and C}

Liver is an organ that processes almost everything put into body, including drugs. The three most common types of viral hepatitis (A, B, and C) can damage liver.

Some of the same behaviours that put people at risk for HIV (unprotected sex, injection drug use) can put them at risk for hepatitis.

If you have both HIV and hepatitis B or C, your treatments for either disease can be affected. If you have HIV, your hepatitis may progress faster. If your liver is damaged 
from hepatitis, it may be harder for your body to process your HIV medications. What's more, some HIV treatments can damage your liver, so if you have hepatitis, your doctor may want you to try other treatments

In conclusion, hepatotoxicity of Ritonavir, Indinavir, Saquinavir, Nelfinavir became more evident after the introduction of ART (Anti retrovirals) of high activity, which initially included invariably protease Inhibitors.

Based on the review of drug induced hepatotoxicity, it has been found that none of the studies has been able to prove the higher potential for liver toxicity of this particular family of drugs.

Among the PI's, in some studies full dose ritonavir (RTV) has been found to be more hepatotoxic.(41) Although these results have not been confirmed by others. $(42,43)$ In certain cases, RTV has caused fatal acute hepatitis.(44) Several cases of liver toxicity associated with the use of indinavir (IDV) and saquinavir (SQV) have also been reported.(45) Nelfinavir was found to be less hepatotoxic than the other PI's analyzed (RTV, IDV, SQV, APV) in study evaluating 1052 patients. (46)

\section{References}

1. Miedema, JAIDS Journal of Acquired Immune Deficiency Syndromes:June 2007 Volume 45 - Issue 2 - pp 183-192 doi: 10.1097/QAI.0b013e31804d685b Clinical Science.

2. Edward L. Murphy, Highly Active Antiretroviral Therapy Decreases Mortality and Morbidity in Patients with Advanced HIV Disease, nn Intern Med. 2001;135(1):17-26.

3. Side Effects of Anti-HIV Medications Health Information for Patients October 2005, 1-301-315-2816
4. Marina NúñezEmail authorVincent Soriano, Hepatotoxicity of Antiretrovirals, Incidence, Mechanisms and Management, January 2005, Volume 28, Issue 1, pp 53-6

5. Nunez M. Hepatotoxicity of antiretrovirals:incidence, mechanisms and management. J Hepatol 2006;44(1 Suppl):S132-S139.

6. Baylor MS, Johann-Liang R. Hepatotoxicity associated with nevirapine use. J Acquir Immune Defic Syndr 2004;35(5):538-9.

7. Wit FW, Weverling GJ, Weel J, Jurriaans S, Lange JM. Incidence of and risk factors for severe hepatotoxicity associated with antiretroviral combination therapy. J Infect Dis 2002;186(1):23-31

8. Gonzalez de RD, Nunez M, Jimenez-Nacher I, Soriano V. Liver toxicity caused by nevirapine. AIDS 2002;16(2):290-1.

9. Revised nevirapine insert. AIDS Patient Care STDS 2001;15(2):103-4.

10. FDA alerts doctors to Prezista's possible link to liver damage, deaths. AIDS Read 2008;18(5):235.

11. McGovern B. Hepatic safety and HAART. J Int Assoc Physicians AIDS Care (Chic Ill ) 2004;3 Suppl 2:S24-S40.

12. Pineda JA, Santos J, Rivero A, Abdel-Kader L, Palacios R, Camacho A, et al. Liver toxicity of antiretroviral combinations including atazanavir/ritonavir in patients coinfected with HIV and hepatitis viruses: impact of pre-existing liver fibrosis. J Antimicrob Chemother 2008;61(4):925-32.

13. Saves M, Raffi F, Clevenbergh P, Marchou B, Waldner-Combernoux A, Morlat P, et al. Hepatitis $B$ or hepatitis $C$ virus infection is a risk factor for severe hepatic cytolysis after initiation of a protease inhibitor-containing antiretroviral regimen in human immunodeficiency virus-infected patients. The APROCO Study Group. Antimicrob Agents Chemother 2000;44(12):3451-5.

14. Sulkowski M, Thomas D, Chaisson R, et al. Hepatotocity associated with antiretroviral therapy in adults infected with antiretroviral therpy in adults infected with HIV and role of Hepatitis $\mathrm{C}$ and $\mathrm{B}$ virus infection. JAMA 2000; 283:74-80

15. Brau N, leaf H, wieczorek R, Margolis D. Severe hepatotoxicity in three AIDS patients 
treted with indinavir. Lancet 1997; 349:9245.

16. Matsuda J, Gohchi K, Yamanka M. Severe hepatitis in patients with AIDS and Hemophilia B treated with indinavir. Lancet 1997; 350: 364.

17. Rodriguez - Rosado R, Garcia- samaniego J, Soriano V. Hepatotoxicity after introduction of highly active antiretroviral therapy. AIDS 1998; 12;1256.

18. Zucker S, quin $\mathrm{x}$, Rouster $\mathrm{S}$,et al. Mechanism of indinavir- induced hyperbilirubinemia. Proc Natl Acad Sci USA 2001;98:12671-6

19. Malaty L, Kuper J Drug interaction of HIV Protease Inhibitor. Drug Saf 1999;20:14769.

20. Dieterich D, Fischl M, Rimland D, et al. The safety and efficacy of Protease Inhibitors in HCV co- infected patients. $9^{\text {th }}$ CROI. Seattle 2002 [abstract 663- M].

21. Pedneault L, Brothers C, Pagano G, et al. Safety profile of amprenavir in the treatment of adult and pediatric patients with HIV infection. Clin Therap 2000;22:1378-94.

22. Fortovase (saquinavir). Prescribing information-USA. Nutley, NJ: Roche Laboratories, 1998.

23. Crixivan (indinavir sulfate). Prescribing information-USA. Whitehouse Station, NJ: Merck and Co., 2001.

24. Norvir (ritonavir). Package insert (USA). North Chicago, IL: Abbott Laboratories, 1999.

25. Kaletra (lopinavir/ritonavir) capsules and oral solution. Prescribin.

26. Viracept (nelfinavir). Prescribing information-USA. San Diego, CA:Agouron Laboratories, 1999.

27. Reyataz (atazanavir sulfate). Prescribing information (USA). Princeton, NJ: Bristol Myers Squibb, 2003.

28. Saves M, Vandentorren S, Daucourt V, et al. Severe hepatic cytolysis: incidence and risk factors in patients treated by antiretroviral combinations combinations. Aquitaine Cohort, France, 1996-1998. Groupe d'Epidemiologie Clinique de Sida en Aquitaine (GECSA). AIDS 1999; 13:F11521.
29. Sulkowski MS, Thomas DL, Chaisson RE, Moore RD. Hepatotoxicity associated with antiretroviral therapy in adults infected with human immunodeficiency virus and the role of hepatitis $\mathrm{C}$ or $\mathrm{B}$ virus infection. JAMA 2000; 283:74-80.

30. Saves M, Raffi F, Clevenbergh P, et al. Hepatitis B or hepatitis C virus infection is a risk factor for severe hepatic cytolysis after initiation of a protease inhibitor-containing antiretroviral regimen in human immunodeficiency virus-infected patients. The APROCO Study Group. Antimicrob Agents Chemother 2000; 44:3451-5.

31. Den Brinker M, Wit FW, Wertheim-van Dillen PM, et al. Hepatitis B and C virus coinfection and the risk for hepatotoxicity of highly active antiretroviral therapy in HIV-1 infection. AIDS 2000; 14:2895-902.

32. Gisolf EH, Dreezen C, Danner SA, Weel JL, Weverling GJ. Risk factors for hepatotoxicity in HIV-1-infected patients receiving ritonavir and saquinavir with or without stavudine. Prometheus Study Group. Clin Infect Dis 2000; 31:1234-9.

33. Nunez M, Lana R, Mendoza JL, MartinCarbonero L, Soriano V. Risk factors for severe hepatic injury after introduction of highly active antiretroviral therapy. J Acquir Immune Defic Syndr 2001; 27:426-31.

34. Monforte Ade A, Bugarini R, Pezzotti P, et al. Low frequency of severe hepatotoxicity and association with HCV coinfection in HIV-positive patients treated with HAART. J Acquir Immune Defic Syndr 2001; 28: 114-23.

35. Bonfanti P, Landonio S, Ricci E, et al. Risk factors for hepatotoxicity in patients treated with highly active antiretroviral therapy. J Acquir Immune Defic Syndr 2001; 27:3168.

36. Wit FW, Weverling GJ, Weel J, Jurriaans S, Lange JM. Incidence of and risk factors for severe hepatotoxicity associated with antiretroviral combination therapy. J Infect Dis 2002; 186:23-31.

37. R. B. Kim, M. F. Fromm, C. Wandel et al., "The drugtransporter P-glycoprotein limits oral absorption and brain entry of HIV-1 protease inhibitors," Journal of Clinical 
Investigation, vol. 101, no. 2, pp. 289-294, 1998.

38. R. B. Pollard, "Use of proteinase inhibitors in clinical practice," Pharmacotherapy, vol. 14, no. 6, pp. 21S-29S, 1994

39. L. S. Lee, A. S. A. Andrade, and C. Flexner, "Interactions between natural health products and antiretroviral drags: pharmacokinetic and pharmacodynamic effects," Clinical Infectious Diseases, vol. 43, no. 8, pp. 1052-1059, 2006.

40. T. A. Knox, L. Oleson, L. L. Von Moltke, R. C. Kaufman, C. A. Wanke, and D. J. Greenblatt, "Ritonavir greatly impairs CYP3A activity inHIV infection with chronic viral hepatitis,"Journal of Acquired Immune Deficiency Syndromes, vol. 49, no. 4, pp. 358-368, 2008.

41. Bofanti P, Landonia S., Ricci E., Artinelli C., Fortuna P., Faggion I., Quirino T. Risk factors for Hepatotoxicityin patients treated with highly active Antiretroviral therapy. J Acquir Immune Defic Syndr. 2001;27:316318.
42. Cooper C., Parbhakar M., Angel J. Hepatotoxicity associated with antiretroviral therapy containing dual versus single protease inhibitors in individuals co infected with hepatitis $\mathrm{C}$ virus and HIV. Clin Infect Dis.2002;34:1259-1263.

43. Aceti A, Pasquazzi C, Zechini B, for the LIVERHAART Group. Hepatotoxicity development during antiretroviral therapy containing protease inhibitors in patients with HIV: the role of hepatitis B and C virus infection. J AIDS 2002, 29:41-48.

44. Pai V., Koranyi K., Nahata M. Acute Hepatitis and Bleeding Possibly induced by Zidovudine and Ritonavir in an infant with HIV infection. Pharcother. 2000;20: 11351140.

45. Sulwoski M. Hepatotoxicity associated with Antiretroviral therapy containg HIV- I Protease Inhibitors. Semin Liver Dis, 2003; 23:183-194

46. Kontorinis N,. Dieterich D. Hepatotoxicity of Antiretroviral therapy. AIDS Rev. 2003;5: 36-43.

\section{How to cite this article:}

Chopra, V.S., Mani Goel, Jyoti Batra, Jyotsna Sharma and Kavita Dhar. 2017. Antiretroviral Therapy that Includes, Protease Inhibitors - Induced Hepatotoxicity: A Review. Int.J.Curr.Microbiol.App.Sci. 6(1): 910-916. doi: http://dx.doi.org/10.20546/ijcmas.2017.601.107 